\title{
Study the Effect of Counseling on Early Initiation of Breastfeeding with Media Breastfeeding E-books
}

\author{
Elsa Budi Sihsilya Rahmawati ${ }^{1}$, Poppy Farantia Saputri ${ }^{1}$ \\ ${ }^{1}$ DIII Midwifery Study Program, STIKes Widya Cipta Husada \\ Email: elsabudisihsilya@gmail.com
}

Received 20 September 2018; Accepted 1 February 2019; Published 22 May 2019

\begin{abstract}
Early Initiation of Breastfeeding is the first step in the success of a baby to learn to suckle first early after birth so that breastmilk remains in production. The coverage of Early Initiation of Breastfeeding is still very low in 2010 (29.3\%) and in 2013 it became (34.5\%). This study aims to analyze the influence of e-book Successful Breastfeeding on the Practice Early Initiation of Breastfeeding in pregnant women $3^{\text {rd }}$ trimester. The research design used a quasi experiment design with pre-post-test control group design. The study was conducted on 54 pregnant women $3^{\text {rd }}$ trimester with purposive sampling method which was carried out in March-June 2018. Data analysis used an independent t-test and Chi square test. The results showed that there was an effect of e-book on knowledge of pregnant women ( $p$ value 0.00). Counseling with Successful Breastfeeding e-books affects the Practice of Early Initiation of Breastfeeding ( $p$ value 0.017). A commitment is needed from all health workers, especially those related to pregnant women and giving birth to provide counseling related to the importance of Early Initiation of Breastfeeding.
\end{abstract}

Keywords: E-Book, early initiation of breastfeeding

Copyright $\odot 2019$ STIKes Surya Mitra Husada

All right reserved.

This is an open-acces article distributed under the terms of the Creative Commons AttributionShareAlike 4.0 International License.

\section{INTRODUCTION}

Essential care is needed in newborns in order to prevent complications and can save the baby's life such as immediately drying the body of a newborn baby and initiation of Early Initiation of Breastfeeding is necessary for the baby's efforts to survive and delay all other care at least one hour at the beginning of the birth (WHO, 2013 ) Early Initiation of Breastfeeding (EIBF) is the process of baby feeding immediately after birth, where the baby is left to look for his mother's nipple. EIBF can prevent $22 \%$ of deaths in infants under the age of 28 months in developing countries. EIBF performed 2-24 hours after birth can prevent $16 \%$ of infant deaths under the age of 28 days (Edmond, 2006). Early initiation of breastfeeding has a positive impact on both mother and baby. Breastmilk that first comes out after labor or called colostrum contains substances that are rich in antibodies that can kill germs in the baby's intestine and serves as an ideal laxative to clean up unused substances from the intestines of the newborn so that the baby's channels are ready to receive future food (Yulianti, 2013). Movement of the baby kicking on the mother's stomach when looking for nipples can help remove the placenta from the uterus and prevent postpartum bleeding (Susanti, 2013).

The percentage of the process of getting breastmilk less than one hour (EIBF) for children aged 0-23 months in Indonesia is still low at $29.3 \%$ in 2010 to $34.5 \%$ in 2013 . The highest percentage of EIBF in West Nusa Tenggara Province ( NTB) (52.9\%), National EIBF coverage is $34.5 \%$ and 
there are 18 provinces whose coverage is below the national figure including East Java province (32\%) (Kemenkes RI, 2013). The percentage of newborns who received EIBF in 2016 was 51.9\% which consisted of $42.7 \%$ getting EIBF in $<1$ hour after birth, and 9.2\% in one hour or more (Kemenkes RI, 2016). The number of infant deaths in Malang Regency according to Puskesmas report in 2011 live births amounted to 40,655, neonatal deaths by 219 (5.39 per 1,000 live births) in 2012 live births amounted to 40,792 (Male 20,589, female 20,203), neonatal infant mortality was as large as 199 (5.39 per 1,000 live births). Exclusive breastmilk achievements in 2012 amounted to $57.9 \%(25,689$ of 44,367) surveyed, while in $201179.8 \%$ (15374 of 19,270) were surveyed (Patilima, 2013). Based on a preliminary study conducted by researchers in Sumberejo Village, on June 14, 2017, of the 15 mothers who had infants aged 0-28 days, it was found that $73.3 \%$ of mothers did not take EIBF at the time of delivery and only $20 \%$ of mothers gave exclusive breastfeeding to their babies.

The EIBF will determine the success of subsequent breastfeeding, because mothers who give breast milk in the first hour after giving birth have a 2-8 times greater chance of exclusive breastfeeding (Yulianti, 2013). This initial contact is a sensitive period, so if it's too late, the child's development and successful breastfeeding will be disrupted. The existence of the EIBF program will prevent neonatal deaths caused by infection and will also succeed in the breastfeeding program. While the benefits for the mother is breastfeeding can reduce morbidity and mortality because the process of breastfeeding will stimulate uterine contractions so as to reduce postpartum bleeding (postpartum) (Rusli, 2008). Various ways for mothers to get knowledge related to breastfeeding preparation, and media are one of the important components in delivering health education. According to the function as a health education media message channel can be grouped on print media, electronic media and media boards (billboards). Referring to the theory of S-O-R (Stimulus, Organism, Response) that a response both closed and open is influenced by a stimulus (Notoatmodjo, 2010). In this case the researcher uses the stimulus in the form of electronic media by using e-book Breastfeeding Success developed from the policy 10 Steps Towards Breastfeeding Success. The purpose of this study was to find out the influence of e-book media Breastfeeding Success on the Practice of Early Initiation of Breastfeeding (EIBF). From the background above so researchers are interested in influencing the ebook Breastfeeding Success on the practice of Early Initiation of Breastfeeding (EIBF).

\section{MATERIALS AND METHODS}

The design of this study is a quasi-experimental design with a pre-post test with control group design. The subjects of this study were pregnant women $3^{\text {rd }}$ trimester from March to June 2018 who met the inclusion and exclusion criteria, with purposive sampling technique and obtained a sample of 54 pregnant women of $3^{\text {rd }}$ trimester who were divided into experiment groups and control groups with criteria for pregnant women $3^{\text {rd }}$ trimester, the intervention group is a mother who has an android cellphone, if the mother or baby dies during the birth process, giving birt by cesarean delivery then it is expelled from the research subject. The intervention provided was counseling with Successful Breastfeeding e-book media which was conducted as many as 3 meetings during $3^{\text {rd }}$ trimester pregnancy. The data used in the study are primary data including the characteristics of respondents, data on knowledge, attitudes and practices of EIBF. The data consisted of pre test (before being given intervention) and post test (after intervention). Data on pre test and post test knowledge and attitudes and practices of EIBF were collected using a questionnaire. Data analysis using independent $t$ test and Chi square test. 


\section{RESULTS}

Table of Respondent Characteristic

\begin{tabular}{|c|c|c|c|c|c|c|c|}
\hline & \multirow[t]{2}{*}{ Variable } & \multicolumn{2}{|c|}{$\begin{array}{c}\text { Experiment } \\
\text { Group }\end{array}$} & \multicolumn{2}{|c|}{$\begin{array}{c}\text { Control } \\
\text { Group }\end{array}$} & \multicolumn{2}{|c|}{$\begin{array}{l}\text { Number \& } \\
\text { Percentage }\end{array}$} \\
\hline & & $\mathrm{N}$ & $(\%)$ & $\mathrm{N}$ & $(\%)$ & $\mathrm{N}$ & $(\%)$ \\
\hline \multirow{2}{*}{ Age } & Not at risk (20-35 year old) & 26 & $(96,3)$ & 25 & $(92,6)$ & 51 & $(94,4)$ \\
\hline & At risk $<20$ dan $>35$ year old & 1 & $(3,7)$ & 2 & $(7,4)$ & 3 & $(5,6)$ \\
\hline \multirow{3}{*}{ Parity } & Primipara & 7 & $(25,9)$ & 9 & $(33,4)$ & 16 & $(29,6)$ \\
\hline & Multipara & 19 & $(70,4)$ & 17 & $(62,9)$ & 36 & $(66,7)$ \\
\hline & Grandemulti & 1 & $(3,7)$ & 1 & $(3,7)$ & 2 & $(3,7)$ \\
\hline \multirow{2}{*}{$\begin{array}{c}\text { Education } \\
\text { Level }\end{array}$} & High (> Junior High school ) & 22 & $(81,5)$ & 17 & $(62,9)$ & 39 & $(72,2)$ \\
\hline & Low ( $\leq$ Junior High school) & 5 & $(18,5)$ & 10 & $(37,1)$ & 15 & $(27,8)$ \\
\hline \multirow[t]{3}{*}{$\begin{array}{l}\text { Mother's } \\
\text { job }\end{array}$} & houswife (jobless) & 21 & $(77,8)$ & 24 & $(88,9)$ & 45 & $(83,3)$ \\
\hline & Working mother & 6 & $(22,2)$ & 3 & $(1,1)$ & 9 & $(16,7)$ \\
\hline & & 27 & (100) & 27 & $(100$ & 54 & $(100)$ \\
\hline
\end{tabular}

Source: Primary Data, 2018

Based on the table above the age of mothers in the intervention group the majority of the age of not at risk (20-35 years) were 26 people (96.3\%), as well as in the control group as many as 51 people (94.4\%) were not at risk. Based on parity, both the experiment group and the dominant control group were multiparous. Maternal education in both the intervention group and the control group was mostly highly educated $(62.9 \%)$. Based on the work both in the intervention group (77.8\%) and the control group (88.9\%) were housewives.

Frequency Distribution of research subject based on Kind of delivery

\begin{tabular}{cccccccc}
\hline \multirow{2}{*}{ Variabel } & & \multicolumn{2}{c}{ EIBF } & \multicolumn{2}{c}{ Without EIBF } & \multicolumn{2}{c}{$\begin{array}{c}\text { Number \& } \\
\text { Percentage }\end{array}$} \\
\cline { 3 - 8 } & & $\mathrm{N}$ & $\%$ & $\mathrm{~N}$ & $\%$ & $\mathrm{~N}$ & $\%$ \\
\hline \multirow{2}{*}{ Kind of delivery } & $\begin{array}{c}\text { Spontaneous } / \\
\text { normal }\end{array}$ & 35 & $(76,8)$ & 10 & $(22,2)$ & 45 & $(100)$ \\
\hline \multirow{2}{*}{ Delivery attendants } & Midwife & 32 & $(82,1)$ & 7 & $(17,9)$ & 39 & $(100)$ \\
\cline { 2 - 8 } & Doctor & 6 & $(40)$ & 9 & $(60)$ & 15 & $(100)$ \\
\hline
\end{tabular}

Source: Primary Data, 2018

Characteristics of respondents based on type of childbirth, the majority of respondents who gave birth spontaneously had a tendency to do Early Initiation of Breastfeeding at the time of delivery (76.8\%), while respondents who gave birt by cesarean delivery it is expelled from the research. Based on birth attendants, the majority of respondents whose birth process was helped by midwives carried out Early Initiation of Breastfeeding (EIBF) (82.1\%), while the respondents who gave birth to the majority of doctors did not carry out Early Initiation of Breastfeeding (60\%). 


\begin{tabular}{|c|c|c|c|c|c|c|c|}
\hline & & \multicolumn{4}{|c|}{ Pre Test } & \multicolumn{2}{|c|}{ Mean } \\
\hline & & \multicolumn{2}{|c|}{$\begin{array}{l}\text { Experiment } \\
\text { Group }\end{array}$} & \multicolumn{2}{|c|}{$\begin{array}{c}\text { Control } \\
\text { Group }\end{array}$} & \multirow[t]{2}{*}{ Experiment } & \multirow[t]{2}{*}{ Control } \\
\hline & & $\mathbf{N}$ & $\%$ & $\mathbf{N}$ & $\%$ & & \\
\hline \multirow{3}{*}{ Knowledge } & Good & 6 & 22,2 & 6 & 22,2 & \multirow{3}{*}{69,25} & \multirow{3}{*}{64,07} \\
\hline & Moderate & 21 & 77,8 & 19 & 70,4 & & \\
\hline & Poor & 0 & 0 & 2 & 7,4 & & \\
\hline \multirow{4}{*}{ Attitude } & Good & 4 & 14,8 & 7 & 25,9 & \multirow{4}{*}{69,29} & \multirow{4}{*}{71.91} \\
\hline & Moderate & 23 & 85,2 & 20 & 74,1 & & \\
\hline & Poor & 0 & 0 & 0 & 0 & & \\
\hline & & 27 & 100 & 27 & 100 & & \\
\hline
\end{tabular}

Source: Primary Data, 2018

Pre Test of knowledge and Attitude of Early Breastfeeding before intervention given before being given the intervention, the study subjects were given pre-test knowledge and attitudes about Early Initiation of Breastfeeding by questionnaire. Knowledge and attitude of the research subject based on the pre-test value is the knowledge of respondents before being given intervention with ebook majority at a sufficient level of knowledge, both in the intervention group (77.8\%) and the control group (70.4\%). Respondents' attitude before being given intervention with e-book majority at a sufficient level both in the intervention group $(85.2 \%)$ and the control group $(74.1 \%)$. The average value of knowledge of respondents in the intervention group (69.25), while the average knowledge in the control group (64.07). The average value of the attitude of the intervention group (69.29) while the average attitude of the control group (71.91).

Post Test Knowledge, Attitude and Early Initiation of Breastfeeding practice (EIBF) after intervention

\begin{tabular}{|c|c|c|c|c|c|c|c|c|}
\hline \multirow{3}{*}{ Variabel } & & \multicolumn{4}{|c|}{ Post Test } & \multicolumn{2}{|c|}{ Mean } & \multirow{3}{*}{$\begin{array}{c}\text { T-Test / } \\
\text { Chi } \\
\text { square }\end{array}$} \\
\hline & & \multicolumn{2}{|c|}{ Intervention } & \multicolumn{2}{|c|}{ Control } & \multirow[t]{2}{*}{ Intervention } & \multirow[t]{2}{*}{ Control } & \\
\hline & & $\mathrm{N}$ & $\%$ & $\mathrm{~N}$ & $\%$ & & & \\
\hline \multirow{3}{*}{ knowledge } & Good & 27 & 100 & 9 & 33,3 & \multirow{4}{*}{85,56} & \multirow{4}{*}{72,9} & \multirow{4}{*}{$0,00 *$} \\
\hline & Moderate & 0 & 0 & 18 & 66,7 & & & \\
\hline & Poor & 0 & 0 & 0 & 0 & & & \\
\hline & & 27 & 100 & 27 & 100 & & & \\
\hline \multirow{3}{*}{ Attitude } & Good & 27 & 100 & 22 & 81,5 & \multirow{3}{*}{87,5} & \multirow{3}{*}{84,41} & \multirow{3}{*}{0,184} \\
\hline & Moderate & 0 & 0 & 5 & 18,5 & & & \\
\hline & Poor & 0 & 0 & 0 & 0 & & & \\
\hline & & 27 & 100 & 27 & 100 & & & \multirow{4}{*}{$0,031 *$} \\
\hline \multirow{3}{*}{$\begin{array}{l}\text { Practice of EIBF } \\
\text { in Vaginal } \\
\text { Delivery }\end{array}$} & EIBF & 23 & 95,8 & 15 & 71,4 & & & \\
\hline & Without & 1 & 4,2 & 6 & 28,6 & & & \\
\hline & & 24 & 100 & 21 & 100 & & & \\
\hline
\end{tabular}

Source: Primary Data, 2018

Based on the table above, all respondents given counseling interventions with Successful Breastfeeding e-book media had good knowledge regarding Early Initiation of Breastfeeding (100\%), while the majority control group's knowledge was at a sufficient level (66.7\%). Respondents' attitude in the intervention group as a whole (100\%) at a good level, in the control group there was an increase in attitudes, the majority of respondents in the majority control group had a good attitude $(81.5 \%)$ related to Early Initiation of Breastfeeding (EIBF). Based on the independent t-test test, treatment in 
the form of counseling with Successful Breastfeeding e-book media affected the mother's knowledge (p value 0.00). Successful Breastfeeding E-book does not affect the mother's attitude (p value 0.184). Based on Chi square e-book test Breastfeeding Success influences the practice of Early Initiation of Breastfeeding ( $\mathrm{p}$ value 0.031). The average knowledge of the group given the intervention was 85.56, while the average knowledge of the control group (72.9). The average attitude after treatment in the intervention group was 87.5.

\section{DISCUSSION}

\section{Mother's Knowledge}

Early Initiation of Breastfeeding (EIBF) has many benefits for babies, contact with mother's skin can reduce the risk of death due to hypothermia, babies get good bacteria from the mother's skin when looking for nipples where good bacteria make colonies in the intestine and baby's skin to compete with harmful bacteria from the environment. Babies get colostrum which contains antibodies so the baby doesn't get sick easily (Sembiring, 2017). The implementation of EIBF is a breakthrough to reduce infant morbidity and mortality. Counseling with e-book Successful Breastfeeding media shows an increase in knowledge of mothers before and after being given intervention. Providing counseling with e-book media can have a positive effect on your knowledge ( $\mathrm{p}$ value 0.009 ). Mothers who have a higher education will respond rationally to information that comes and thinks how far they will get the benefits (Notoatmodjo, 2010). The participation of mothers in the class of pregnant women influences the knowledge of EIBF mothers (Rahmawati, 2016). In line with Mabud's (2016) study, there is a relationship between the level of maternal education and exclusive breastfeeding. There is a difference in the proportion between exclusive breastfeeding between highly educated and low-educated mothers (Mabud, 2016). The majority of maternal education is the most with the level of having higher education (SMA). The results of the mother's knowledge after being given counseling with the overall e-book media have good knowledge, the majority of mothers who have higher education are easier to receive EIBF knowledge. Mothers who have a high level of education tend to be more open-minded and will be more active to find information about their pregnancy through health workers and from various media, such as the internet, print media, etc. so that mothers think they can get information (Prasetyono, 2012). Mother's knowledge influences the implementation of EIBF. High maternal education affects 5.9 times more than mothers with low education levels (Sirajuddin, 2013).

Knowledge is a closed response that is dominant in the formation of actions, behavior based on knowledge will be more lasting. The better maternal knowledge about EIBF will encourage mothers to give ASI as early as possible to their babies (Yasita, 2013). The level of knowledge will influence the mother in taking a stand. The level of knowledge is grouped into 6 levels, starting from know, understand, application, analysis, synthesis and evaluation (Rosyid \& Sumarmi, 2017). According to Nuryanti (2013) counseling and education require a relatively long time as well as directed and continuous planning to change into behavior (Nuryanti1, Hadju, \& Jafar, 2013). The qualitative study of Fikawati shows that predisposing factors for failure of exclusive breastfeeding are lack of mother's knowledge and failure enabling factors because mothers are not facilitated with EIBF. EIBF has been proven to increase the success of exclusive breastfeeding (Fikawati \& Syafiq, 2010). So that it is expected that health workers have a high commitment to provide ongoing EIBF counseling both on antenatal and intranatal visits to establish good knowledge about EIBF in mothers.

\section{Mother's attitude}

Successful Breastfeeding E-book does not affect the mother's attitude in EIBF ( $p$ value 0.184). Good maternal knowledge is not balanced with a good attitude towards EIBF, the implementation of EIBF requires the support of husband and family. Mother's emotional condition determines a positive or negative mother's attitude towards EIBF. Other causes that influence attitudes are the situation and condition of mothers who are still exhausted during childbirth. With family support can make mothers more calm and comfortable so that they have a positive attitude towards EIBF (Sirajuddin, Abdullah, \& Lumula, 2013). The results of this study contrast with Husnah's (2014) 
study that mothers who received prenatal and perinatal counseling and motivation had a positive attitude compared to mothers who did not get counseling and motivation about EIBF (Husnah, 2014).

Attitude is a reaction or response that is still closed from someone to a stimulus or object. Attitudes are not necessarily realized in the form of action, because to realize the action need other factors, namely maternal mental readiness and support of facilities or facilities and infrastructure as mediators so that attitudes can be increased into action (Maulana, 2010). Attitude factors do not affect the practice of EIBF. Attitude is still a convert behavior meaning it is still a closed behavior and not necessarily manifest in an action (overt behavior). To realize the attitude of being overt behavior requires supporting factors and possible situations such as the readiness of mothers to face childbirth, maternal readiness for EIBF, the presence of EIBF facilities, childbirth support, etc. (Rahmawati, 2015). In the process of initiation of early breastfeeding, the mother's mental readiness is needed, the mother should not feel uncomfortable when the baby is placed on her body. At this time, support from health workers, families, especially husbands, is needed by mothers who will initiate early breastfeeding after giving birth (Prasetyono, 2012). So in this case the role of husbands and health workers in shaping the readiness of pregnant women in the face of childbirth and readiness to face a new role of being a mother is needed so that maternal attitudes can be positive regarding Early Initiation of Breastfeeding (EIBF) and can turn into Early Initiation of Breastfeeding behavior (EIBF). Mothers with good knowledge do not necessarily have a good attitude about Early Initiation of Breastfeeding (EIBF), this can be triggered by a factor in the experience of previous deliveries. The majority of respondents were multigravidas, gave birth spontaneously and were helped by Midwives.

\section{Early Initiation of Breastfeeding Practices (EIBF)}

Counseling with Successful Breastfeeding e-books affects the EIBF Practice (p value 0.002). The mother group that was given intervention with e-book media was dominant in EIBF during childbirth. Based on the theory of Stimulus Organism Response (SOR) is based on the assumption that the cause of behavior change depends on the excitatory qualities (stimulus) that communicate with the organism. Behavior is the result of all kinds of experiences and human interaction with the environment which is manifested in the form of knowledge, attitudes and actions. behavior is the response / reaction of an individual to a stimulus that comes from outside or from within him (Notoatmodjo, 2010). Where the stimulus given in this study is counseling with e-book media. In this study counseling with e-book media Success of breastfeeding has an effect on maternal knowledge and EIBF practices. This EIBF behavior can be realized with good maternal knowledge about EIBF and the support of the environment such as family and childbirth health workers. In line with the results of previous studies that there is a relationship between the support of health workers with the implementation of EIBF in the delivery room of Datoe Binangkang Regional Hospital (Pangerapan, Umboh, \& Lestari, 2018). Success in the breastfeeding process is also determined by the role of fathers in creating a situation that allows early breastfeeding to run smoothly (Yuliarti, 2010). So that the provision of EIBF counseling is expected to be given to every pregnant woman and family because good knowledge is the basis of the mother in developing reason and motivation to do EIBF.

Mothers who gave birth spontaneously had a tendency to EIBF than those who gave birth in caesarean section. Childbirth aids and types of childbirth affect the practice of Early Initiation of Breastfeeding (Rahmawati, 2015). According to Roesli (2010), mothers who give birth in caesarean section can still carry out Early Initiation of Breastfeeding with the help of health workers, namely pro-Iniasiasi Early Breastfeeding doctors, supporting anesthesia doctors and nurses who help hold the baby and are supported by the operating room infrastructure that allows and is ensured there are no complications that accompany the mother and baby. It is hoped that labor assistants for childbirth can provide EIBF counseling for every woman who is giving birth both spontaneously and in caesarean section and facilitates the occurrence of EIBF practices if maternal and infant conditions are possible. The age of respondents who are mostly in reproductive age also has a tendency to carry out Early Initiation of Breastfeeding (EIBF), because mothers who are in reproductive age have less potential to experience labor complications, although labor complications are not always predictable before. Based on the type of labor, the majority of respondents gave birth spontaneously. Respondents who gave birth spontaneously had a tendency to carry out Early Breastfeeding Initiation. In line with the research of Rahmawati (2016) that the type of labor affects the practice of Early Breastfeeding 
Initiation. Mothers who give birth spontaneously can do Early Initiation of Breastfeeding compared to delivery of Caesarean Sectio (Rahmawati, 2015). Spontaneous labor and caesarean section actually have the same opportunities to do EIBF, but the implementation or absence of Early Breastfeeding is also influenced by social support, especially from childbirth helpers, facilities for delivery and the place of birth policy.

The factors that allow the implementation of EIBF are the process of childbirth that is safe for the mother and baby and the condition of the mother and baby after childbirth. In vaginal delivery not all deliveries experience success in the process of implementing Early Breastfeeding Initiation, but there are also some respondents who fail in the process of implementing Early Breastfeeding Initiation. Likewise, in labor, not all gestures will experience failure in the process of implementing Early Breastfeeding Initiation, but there are some respondents who experience success in the process of implementing Early Initiation of Breastfeeding (Putri, 2017). Maternal complications in labor, caesarean section delivery and lack of guidelines for EIBF policy after caesarean delivery are related to EIBF practices. Caesarean delivery is reported to be a major risk factor for delayed EIBF and an increased risk of pralactation feeding. Infants born at caesarean are at risk of not being breastfed within the first hour of birth. The effects of anesthesia, caesarean section reduce alertness and make the mother feel uncomfortable starting breastfeeding. Caesarean delivery is closely related to complications in the mother or baby. (Vishnu, 2015). In this study respondents who gave birt by cesarean delivery it is expelled from the research to minimize bias.

Republic of Indonesia Government Regulation Number 33 of 2012 concerning Exclusive Maternal Feeding, Article 9 (1) "Health Workers and providers of Health Service Facilities must initiate early breastfeeding of newborns to their mothers for at least 1 (one) hour. The shortest time for initiation of early breastfeeding for 1 (one) hour is intended to provide an opportunity for the baby to be able to look for the mother's nipples and suckle herself. In the case of at least 1 (one) hour after giving birth. Babies still do not want to suckle, so Early Initiation of Breastfeeding activities must continue to be pursued by mothers, health workers, and providers of health care facilities " (Kemenkes RI, 2012). Basically, EIBF can still be carried out in all childbirth processes, except for certain medical indications that are determined or decided by the midwife and the team of doctors at the time of delivery. EIBF promotion is very necessary because it contributes greatly to saving newborns and reducing the Infant Mortality Rate. Health facilities such as hospitals, health centers, polindes, independent midwives are the spearheads in implementing this policy. Health workers who accompany mothers during the antenatal period are required to provide EIBF counseling to mothers despite the limited time they have. The health worker in the saloon room must understand the EIBF procedures and want to apply it to the maternity mother, because EIBF is the right of every maternity mother in which this policy is stated in PP No. 33 of 2012 concerning Exclusive Breastfeeding.

\section{CONCLUSION}

Knowledge of pregnant women related to Early Initiation of Breastfeeding increased after being given an Early Initiation of Breastfeeding (EIBF) intervention using e-book Breastfeeding Success media, with a higher average compared to the control group who were not given intervention. Successful Breastfeeding E-books affect the practice of Early Initiation of Breastfeeding (EIBF). Interventions to provide counseling for Early Initiation of Breastfeeding (EIBF) for pregnant women are important to be carried out both directly and through health cadres, as well as the commitment of health workers who help childbirth to continue to provide Early Initiation of Breastfeeding (EIBF) and apply it during labor both spontaneously and caesarean section if maternal and fetal conditions are possible. 


\section{REFERENCE}

Edmond, K., M. (2006). Delayed Breastfeeding Initiation Increases Risk of Neonatal. Pediatrics Official Journal of The American Academy of Pediatrics, 117, 380-386.

Fikawati, S., \& Syafiq, A. (2010). Kajian Implementasi dan Kebijakan Air Susu Ibu Eksklusif Dan Inisiasi Menyusu Dini di Indonesia. MAKARA KESEHATAN, VOL. 14, NO. 1, 17-24. doi/org/10.7454/msk.v14i1.642.

Husnah. (2014). Pengetahuan dan Sikap Ibu Bersalin dengan Inisiasi Menyusu Dini. Jurnal Kedokteran Syiah Kuala, Vol. 14 Nomor 3, 135-138.

Kemenkes RI. (2012). Peraturan Pemerintah Republik Indonesia Nomor 33 Tahun 2012 tentang Pemberian Air Susu Ibu Eksklusif. Jakarta: Kementrian Kesehatan Republik Indonesia. Diakses 14 September 2018 dari http://pdgmi.org/wp-content/uploads/2016/06/ASI_BUKU-PP-NO-33-2012_ASI_.pdf.

Kemenkes RI. (2013). Profil Kesehatan Indonesia 2013. Jakarta. Diakses 10 September 2018 dari http://www.depkes.go.id/resources/download/pusdatin/profil-kesehatan-indonesia/profil-kesehatan-indonesia2013.pdf.

Kemenkes RI. (2016). Profil Kesehatan Indonesia 2016. Jakarta. Diakses 10 September 2018 dari http://www.depkes.go.id/resources/download/pusdatin/profil-kesehatan-indonesia/Profil-Kesehatan-Indonesia2016.pdf.

Mabud Nurma Hi, P., J. (2016). Faktor-Faktor yang Memengaruhi Pemberian ASI Eksklusif Puskesmas Kota Maba Kecamatan Kota Maba Kabupaten Halmahera Timur. Commuity Health, 41-54.

Maulana, D. (2010). Promosi Kesehatan. Jakarta: Penerbit Buku EGC.

Notoatmodjo. (2010). Promosi Kesehatan Teori dan Aplikasi. Jakarta: Rieneka Cipta.

Nuryanti, Hadju, V., \& Jafar, N. (2013). Early Initiation of Breastfeeding Practice at Sitti Khadijah Mother and Child Hospital Muhammadiyah Makassar Branch. Media Gizi Masyarakat Indonesia, Vol. 2, No. 2, 85-89. Diunduh pada 14 September 2018 dari http://journal.unhas.ac.id/index.php/mgmi/article/view/447.

Pangerapan, N., L., Umboh, A., \& Lestari, H. (2018). Faktor-Faktor yang Berhubungan dengan Pelaksanaan Inisiasi Menyusu Dini (EIBF) Di Rsud Datoe Binangkang. ejournalhealth, 103-109.

Patilima, H. (2013). Kabupaten Kota Layak Anak. Jakarta: Universitas Indonesia. Diakses 8 September 2018 dari https://media.neliti.com/media/publications/229091-kabupaten-kota-layak-anak-6606fe4b.pdf.

Prasetyono, D., S. (2012). Buku Pintar ASI Eksklusif: Pengenalan, Praktik, dan Kemanfaatan-kemanfaatannya. Yogyakarta: DIVA Press.

Putri, R. (2017). Hubungan Jenis Persalinan terhadap Keberhasilan Inisiasi Menyusu Dini (EIBF) di RSUD Bangil Kabupaten Pasuruan. Majalah Kesehatan Fakultas Kedokteran Universitas Brawijaya, Vol. 4, No. 4, 183 192. doi.org/10.21776/ub.majalahkesehatan.2017.004.04.4.

Rahmawati, E., B. (2015). Analisis Pengaruh Kelas Ibu Hamil terhadap Praktik Inisiasi Menyusu Dini. Surabaya: Fakultas Kesehatan Masyarakat Universitas Airlangga. Diunduh pada 7 September 2018 dari http://repository.unair.ac.id/33568/.

Rahmawati, E., B. (2016). Keikutsertaan Kelas Ibu Hamil Berpengaruh terhadap Pengetahuan dan Sikap Ibu dalam Praktik Inisiasi Menyusu Dini. Majalah Obstetri Gynecology, Vol. 24 No. 1, 8-12. doi.org/10.20473/mog.V24I12016.8-12.

Rosyid, Z., N., \& Sumarmi, S. (2017). Hubungan Antara Pengetahuan Ibu dan EIBF Dengan Praktik ASI Eksklusif. Amerta Nutrition, Vol 1, No 4, 406-414. doi.org/10.20473/amnt.v1i4.2017.406-414.

Rusli, U. (2008). Inisiasi Menyusu Dini Plus ASI Eksklusif. Jakarta: Kompas Media Nusantara. 
Sembiring, J., B. (2017). Buku Ajar Neonatus, Bayi, Balita, Anak Pra Sekolah. Yogyakarta: Penerbit Deepublish.

Sirajuddin, S., Abdullah, T., \& Lumula, S., N. (2013). Determinan Pelaksanaan Inisiasi Menyusu Dini. Kesmas National Public Health Journal, Vol. 8, No. 3, 99-103. oi.org/10.21109/kesmas.v8i3.350.

Susanti, F., S. (2013). 132 Jawaban Dokter Untuk Perawatan \& Perkembangan Bayi: 0 - 12 Bulan. (J. R.N, Ed.) Jakarta: PT. Transmedia Anak Kita.

Vishnu Khanal, E., A. (2015). Factors associated with Early Initiation of Breastfeeding in. International Journal of Environmental Research and Public Health, 12, 9562-9574. doi.org/10.3390/ijerph120809562.

WHO. (2013). Early Initiation of Breastfeeding: the Key to Survival and Beyond. (3), 113.

Yasita, N. (2013). Faktor-Faktor Yang Berhubungan dengan Pelaksanaan Inisiasi Menyusu Dini (EIBF) pada Ibu Post Partum di Ruang Bersalin Rumah Sakit Yarsi Pontianak . Comunity Kesehatan, 103-114.

Yulianti. (2013). Studi kualitatif mengenai gambaran niat ibu hamil dalam penerapan proses inisiasi menyusu dini di Rumah Sakit Islam Jakarta. Universitas Indonesia, 50-62. Diunduh pada 10 September 2018 dari http://lib.ui.ac.id/file?file=digital/122571-S\%205274-Studi\%20kualitatif-HA.pdf.

Yuliarti, N. (2010). Keajaiban ASI - Makanan Terbaik Untuk Kesehatan, Kecerdasan dan Kelincahan (1 ed.). (R. Viva, Ed.) Yogyakarta: CV Andi Offset (Penerbit ANDI). 